\title{
Study of Initial Adhesion of a Bacterium to Different Support Materials before and after Conditioning Film of Olive Oil-Mill Wastewater
}

\author{
Taoufik Hakim ${ }^{1}$, Souad Lekchiri', Hassan Latrache ${ }^{1 *}$, Mohamed El Amine Afilal' \\ Abdeslam Jaafari ${ }^{1}$, Safae Tankiouine ${ }^{1}$, Mostafa Ellouali' ${ }^{1}$, Hafida Zahir ${ }^{1}$ \\ ${ }^{1}$ Bioprocess and Biointerfaces Laboratory, Faculty of Sciences and Techniques, Sultan Moulay Slimane University, Beni Mellal, \\ Morocco \\ ${ }^{2}$ Biochemistry and Biotechnology Laboratory, Mohamed First University, Oujda, Morocco \\ Email: *latracheh@yahoo.fr
}

How to cite this paper: Hakim, T., Lekchiri, S., Latrache, H., El Amine Afilal, M., Jaafari, A., Tankiouine, S., Ellouali, M. and Zahir, H. (2020) Study of Initial Adhesion of a Bacterium to Different Support Materials before and after Conditioning Film of Olive Oil-Mill Wastewater. Advances in Bioscience and Biotechnology, 11, 391-404. https://doi.org/10.4236/abb.2020.118027

Received: June 23, 2020

Accepted: August 7, 2020

Published: August 10, 2020

Copyright $\odot 2020$ by author(s) and Scientific Research Publishing Inc. This work is licensed under the Creative Commons Attribution International License (CC BY 4.0).

http://creativecommons.org/licenses/by/4.0/ (c) (i) Open Access

\begin{abstract}
To improve the start-up speed and efficiency of bioreactors, biofilm technology is sometimes used. This technology uses various types of materials to facilitate the adhesion of microorganisms. In this study, the surface characteristics of inert substrates and substrates after olive oil-mill wastewater (OMWW) conditioning film were evaluated to understand the impact of OMWW on adhesion as well as the most suitable material to optimize bacterial adhesion. Three common substrates made of different polymers were tested for bacterial adhesion before and after treatment with OMWW: PP (polypropylene), PET (Polyethylene terephthalate), and PVC (polyvinyl chloride). The surfaces' physicochemical characteristics were studied by measuring the contact angle for the studied bacteria strain and the supports, before and after treatment with OMWW. Results of initial adhesion tests for untreated and treated supports showed differences in how bacterial cells adhered to substrates. Before treatment with OMWW, PVC and then PP showed a significant adhesion capacity, double that of PET [PVC: $1.58 \times 10^{5} \mathrm{CFU} / \mathrm{cm}^{2}$, PP: $1.48 \times 10^{5}$ $\mathrm{CFU} / \mathrm{cm}^{2}$ and PET: $0.72 \times 10^{5} \mathrm{CFU} / \mathrm{cm}^{2}$ ]. After treatment with OMWW, initial bacterial adhesion increased by $10^{6}$ (from $10^{5} \mathrm{CFU} / \mathrm{cm}^{2}$ for untreated supports to $10^{11} \mathrm{CFU} / \mathrm{cm}^{2}$ for treated supports), and PET followed by PP demonstrated the highest adhesion capacity, 2 and 1.7 times more than PVC, respectively [PET: $1.39 \times 10^{11} \mathrm{CFU} / \mathrm{cm}^{2}$, PP: $1.15 \times 10^{11} \mathrm{CFU} / \mathrm{cm}^{2}$ and PVC: $\left.0.67 \times 10^{11} \mathrm{CFU} / \mathrm{cm}^{2}\right]$. OMWW conditioning film affects the physicochemical characteristics of plastic supports, especially the donor electron character, and improves the initial adhesion of bacteria to substrates $\left(10^{5}\right.$ to $\left.10^{11} \mathrm{CFU} / \mathrm{cm}^{2}\right)$. Therefore, surfaces' physicochemical characteristics were important in the in-
\end{abstract}


itial adhesion of the bacteria onto the support before and after treatment.

\section{Keywords}

Conditioning Film, Initial Adhesion, Olive Oil-Mill Wastewater, Physicochemical Properties

\section{Introduction}

Wastewater treatment has become a necessity to meet a dual objective: first, to clean up the environment from excessive organic matter and second, to reuse treated water for irrigation, especially for countries with water shortages. The Mediterranean regions that specialize in the production of olive oil are particularly affected by olive oil-mill wastewater (OMWW), which is harmful to flora and fauna. To lessen the effects of OMWW, several technologies were used including membrane filtration [1], reverse osmosis [2], electrochemical oxidation [3], land treatment [4], and biological treatments such as anaerobic digestion to produce biomethane [5] and aerobic treatment [6]. Methanization not only reduces the organic matter in wastewater but also transforms it into a renewable energy source, i.e. methane. After anaerobic digestion begins, biogas detection only takes place from the second week of start-up [7] due to the time required to accumulate a sufficient amount of biomass to treat the organic matter. The doubling time of acetogenic bacteria and methanogenic archaebacteria is very slow, around ten days. Often, when the content is renewed in a bioreactor, whether anaerobic or aerobic, some of the biomass is lost in the outlet's effluent, which delays the bioprocess [8]. The use of supports within bioreactor responds to several requests, i.e. on the one hand, the microorganisms attach themselves to a surface allowing them to form a stable biofilm, increase the microorganisms surface area of contact with the environment and on the other hand they limit the loss of biomass by the effluents and increase in the start-up speed of the bioreactor after the renewal of its contents. Several types of substrates are used (plastic, sand, stone, zeolite, etc.) to facilitate biofilm formation. Many different studies have concluded that physicochemical characteristics, roughness, $\mathrm{pH}$, ionic strength, and porosity play an important role in the initial adhesion of bacteria to substrates [8]-[14].

One aspect of microorganisms' adhesion to biocarriers that has received little attention is the conditioning film phenomenon: the deposit of nutrients on material surfaces when immersed in a liquid medium [15]. Substances in organic materials such as sugars and proteins can adsorb to surfaces, forming a conditioning film and affecting physicochemical characteristics, roughness, surface charge, and wettability. The conditioning film, in turn, affects the adhesion of bacteria to the surface [15].

To our knowledge, no work has highlighted the effect of OMWW conditioning film or, more generally, any organic material on the supports in the bioreac- 
tor for wastewater treatment. In this work, our objective is to demonstrate how the OMWW conditioning film modifies both the biocarriers' physicochemical characteristics and the bacterium adhesion to substrate surfaces treated and untreated with OMWW.

\section{Materials and Methods}

\subsection{Bacterial Strain and the Preparation of a Bacterial Suspension}

The bacterial strain used as a biological model is an optional anaerobic Gram-positive bacterium from a laboratory digester. This bacterium is added to the consortium of microorganisms in the anaerobic digester to increase the quantity of biogas [16]. The bacteria used are being patented. This strain is grown in a liquid Luria Bertani medium (LBL) at $37^{\circ} \mathrm{C}$ for 24 hours. To remove media residues, the bacteria are then collected by centrifugation (5000 $\mathrm{g}$ for 15 min) and washed twice with a solution of $\mathrm{KNO}_{3}$ at $0.1 \mathrm{M}$ of ionic strength. Finally, the bacterial suspension was prepared with a solution of $\mathrm{KNO}_{3}(0.1 \mathrm{M})$. This ionic solution was used to model the characteristics of a high strength OMWW [17] [18].

\subsection{Plastic Supports}

Three ordinary plastic carrier materials were selected for their low cost, durability, and availability and because they are commonly used as mobile carrier materials in anaerobic digesters: polyethylene terephthalate (PET: $\left.\left(\mathrm{C}_{10} \mathrm{H}_{8} \mathrm{O}_{4}\right)_{\mathrm{n}}\right)$, polypropylene (PP: $\left.\left(\mathrm{C}_{3} \mathrm{H}_{6}\right)_{n}\right)$, and polyvinyl chloride (PVC: $\left.\left(\mathrm{C}_{2} \mathrm{H}_{3} \mathrm{Cl}\right)_{n}\right)$. Each plastic material was cut into $1.5 \mathrm{~cm}^{2}$ square coupons for contact angle measurement experiments, and into $1 \mathrm{~cm}^{2}$ squares for adhesion tests. The plastic supports were immersed in ethanol for $15 \mathrm{~min}$ to disinfect and remove dirt from their surface and subjected to a sonication bath in sterile distilled water for $10 \mathrm{~min}$. The coupons were rinsed several times with sterile distilled water. Then they were dried in a sterile area before being stored in a sterile condition for later use.

\subsection{Experimental Adhesion}

Ten $\mathrm{ml}$ of bacterial suspension containing approximately $10^{8} \mathrm{CFU} / \mathrm{ml}$ was incubated in a petri dish containing PET, PP, PVC coupons (3 coupons for each support, cleaned and disinfected according to the protocol described above) untreated and treated by sterile OMWW for 3 hours at $37^{\circ} \mathrm{C}$. After incubation, the coupons were then rinsed three times with sterile distilled water to remove non-adherent bacteria. The plastic coupons were immersed in test tubes containing sterile physiological water $(\mathrm{NaCl}: 9 \mathrm{~g} / \mathrm{l})$. The bacterial cells were detached from the inert supports using a sonication bath (ultrasonic) for $5 \mathrm{~min}$ [19]. The adhered bacteria were harvested by the sonication method and CFUs were counted using the serial dilution technique of the bacterial suspension (dilution up to $10^{-3}$ in the case of untreated supports and $10^{-9}$ for supports treated with 
OMWW).The experiment was carried out three times.

\subsection{Contact Angle Measurement}

\subsubsection{The Bacteria}

The method for measuring contact angles on bacterial layers has been described by Busscher et al. [20]. Briefly, the prepared bacterial suspension is deposited on a cellulose acetate filter $(0.45 \mu \mathrm{m})$ using a filtration ramp, producing a bacterial mat whose thickness probably represents 50 to 100 cells. This film is placed on a glass support and allowed to evaporate. The contact angle is then measured. Water (w), formamide (f), and diiodomethane (d) were used as reference solvents. A drop is formed at the end of a syringe to be deposited on the sample surface. A sequence of digital images is immediately acquired (Windrop) using a CCD camera placed on a goniometer (GBX Instruments, France). Three measurements are made for each sample and for each solvent. The experiment is repeated three times. The free surface energies are determined: the Lifshitz-Van der Waals $\gamma^{\mathrm{L} \mathrm{W}}$, electron acceptor $\gamma^{+}$, and electron donor $\gamma^{-}$using the equations of Van Oss et al. [21].

In this approach the contact angles $(\theta)$ can be expressed as in Equation (1).

$$
\gamma_{L}(1+\cos \theta)=2 \cdot\left(\sqrt{\gamma_{S}^{\mathrm{LW}} \cdot \gamma_{L}^{\mathrm{LW}}}+\sqrt{\gamma_{S}^{+} \cdot \gamma_{L}^{-}}+\sqrt{\gamma_{S}^{-} \cdot \gamma_{L}^{+}}\right)
$$

And the quantitative hydrophobicity can be estimated by using Equation (2).

$$
\Delta G_{i w i}=-2\left[\left(\left(\gamma_{i}^{\mathrm{LW}}\right)^{\frac{1}{2}}-\left(\gamma_{w}^{\mathrm{LW}}\right)^{\frac{1}{2}}\right)^{2}+2\left(\left(\gamma_{i}^{+} \gamma_{i}^{-}\right)^{\frac{1}{2}}+\left(\gamma_{w}^{+} \gamma_{w}^{-}\right)^{\frac{1}{2}}-\left(\gamma_{i}^{+} \gamma_{w}^{-}\right)^{\frac{1}{2}}-\left(\gamma_{w}^{+} \gamma_{i}^{-}\right)^{\frac{1}{2}}\right)\right]
$$

\subsubsection{The Supports with and without Conditioning Film}

The effect of OMWW conditioning film on supports' physicochemical characteristics was studied by comparing the physicochemical characteristics of these plastic materials before and after their treatment with OMWW. Treatment consisted of immersing the materials in $\mathrm{OMWW}$ for 3 hours at $37^{\circ} \mathrm{C}$ and then drying in a sterile area.

For untreated supports, the contact angle was measured after cleaning, disinfecting, and drying. For treated supports, the contact angle was measured after treatment with OMWW. The basic principle is the same as for bacteria. The contact angles of the supports were measured using the sessile drop technique of the three probe liquids of different polarity and with known surface energy. OMWW was collected from a discontinuous pressing process oil press from Beni Mellal region in Morocco.

\subsection{Statistical Analysis}

Statistical analyses were performed using Software Excel Analysis Toolpack version 2016. t-Test: Two-Sample Assuming Equal Variances was used to compare the means each support before and after treatment with OMWW $(\mathrm{P}<0.05)$. 


\section{Results}

\subsection{Experimental Adhesion of a Bacterium to Supports Treated and Untreated with OMWW}

This section presents results regarding the adhesion power of the selected bacterial strain to several supports that differ by their physicochemical characteristics and by whether they were conditioned in OMWW. The bacterial strain's ability to attach to untreated supports compared to those treated with OMWW is presented in Figure 1.

In Figure 1(a), results of the adhesion tests show a marked among the untreated carrier materials (PET, PP, and PVC) in their ability to promote initial bacteria adhesion [t-test indicates that $(\mathrm{PET})$ is significantly different from (PP, $\mathrm{PVC})(\mathrm{P}<0.05)$ and $(\mathrm{PP})$ is not significantly different from (PVC) $(\mathrm{P}>0.05)]$. PET is the substrate with least colonization by the studied bacterial strain, whereas PVC contains the most of adherent bacteria, followed by PP; both PVC and PP had over 2 times more colonization than PET [PVC: $1.58 \times 10^{5} \mathrm{CFU} / \mathrm{cm}^{2}$; PP: $1.48 \times 10^{5} \mathrm{CFU} / \mathrm{cm}^{2}$; PET: $\left.0.72 \times 10^{5} \mathrm{CFU} / \mathrm{cm}^{2}\right]$. The adhesion on these untreated substrates decreases in this order PVC $>$ PP $>$ PET. Treatment with OMWW increases bacteria adhesion across all supports by a factor of $10^{6}$ (from $10^{5} \mathrm{UFC} / \mathrm{cm}^{2}$ for untreated supports to $10^{11} \mathrm{UFC} / \mathrm{cm}^{2}$ for treated supports)

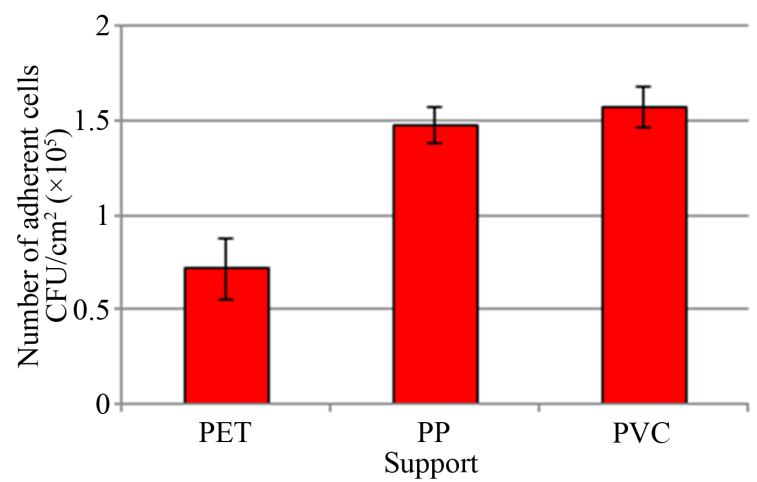

(a)

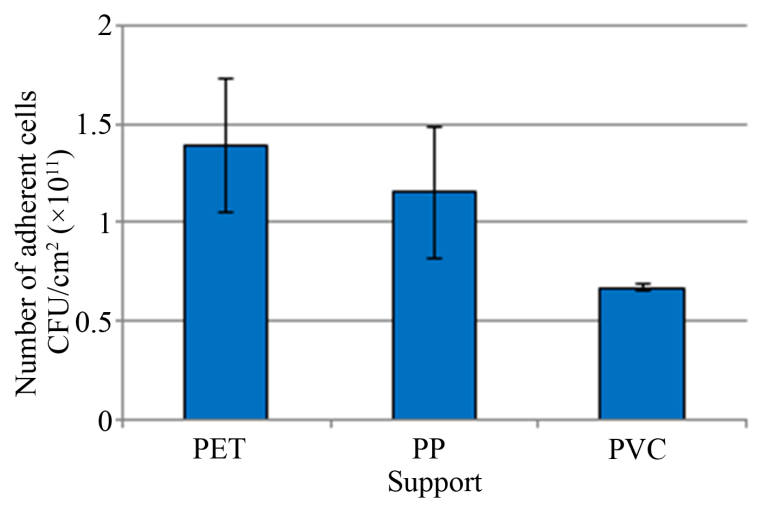

(b)

Figure 1. Number of initial cells adhering to supports. (a) Untreated supports; (b) Treated supports. The error bars represent standard deviations on bacteria counting. 
(Figure 1(b)). After treatment with OMWW, statistically there is no significant difference between each carrier materials to promote bacterial adhesion $(\mathrm{P}>$ 0.05).PVC is the substrate with least colonization by the studied bacterial strain, whereas PET contains the higher colonization (2 times more than PVC), followed by PP (1.7 times more than PVC) [PET: $1.39 \times 10^{11} \mathrm{CFU} / \mathrm{cm}^{2}$; PP: $1.15 \times$ $10^{11} \mathrm{CFU} / \mathrm{cm}^{2}$; PVC: $\left.0.67 \times 10^{11} \mathrm{CFU} / \mathrm{cm}^{2}\right]$. The adhesion on these treated substrates decreases in this order PET $>$ PP $>$ PVC.

\subsection{Surface Energy Components of the Bacterium}

The contact angle measurements of the bacterium were taken and then used to determine the surface energy components (Table 1).

Qualitative analysis of hydrophobicity shows that the contact angle between the bacterial surface and water is $\theta_{w}=33.8^{\circ}$, which means that the bacterium tested has a hydrophilic character. A quantitative approach affirms this result, finding that the strain tested has a positive free surface energy $\left(\Delta G_{i w i}=31.1\right.$ $\left.\mathrm{mj} / \mathrm{m}^{2}\right)$. Moreover, this strain has a strong electron donor character $\left(\gamma^{-}=50.62\right.$ $\left.\mathrm{mj} / \mathrm{m}^{2}\right)$, whereas the electron acceptor properties are very low $\left(\gamma^{+}=0.59 \mathrm{mj} / \mathrm{m}^{2}\right)$. Similar results were found by Nguyen et al. who worked on the Methanosarcina barkeri strain [18]. In light of these results, Latrache et al. have shown that the hydrophobicity measured by the contact angle is directly correlated with the high N/C ratio and inversely correlated with that of $\mathrm{O} / \mathrm{C}$ ratio [22].

\subsection{Plastic Supports' Physicochemical Characters}

The contact angle measurements for the different plastic supports were taken before and after the supports were treated with OMWW and then used to determine the surface energy components (Table 2).

Before treatment with OMWW, all the supports are strongly hydrophobic $\left(\theta_{w}\right.$ $\left.(\mathrm{PET})=80.9^{\circ} ; \theta_{w}(\mathrm{PP})=77.8^{\circ} ; \theta_{w}(\mathrm{PVC})=76.3^{\circ}\right)($ Figure $2(\mathrm{a}))$. Based on the Van Oss approach [21] [23], the quantitative hydrophobicity $\left(\Delta G_{i w i}\right)$ of the three supports have, like the qualitative approach $\left(\theta_{w}\right)$, a hydrophobic character $\left(\Delta G_{i w i}\right.$ $(\mathrm{PET})=-52.2 \mathrm{~mJ} / \mathrm{m}^{2} ; \Delta G_{i w i}(\mathrm{PP})=-46.3 \mathrm{~mJ} / \mathrm{m}^{2} ; \Delta$ Giwi $\left.(\mathrm{PVC})=-43.1 \mathrm{~mJ} / \mathrm{m}^{2}\right)$ (Figure 2(b)). The electron donor $\bar{\gamma}$ character for the three untreated supports have a valor around $5 \mathrm{~mJ} / \mathrm{m}^{2}\left(\gamma^{-}(\mathrm{PET})=4.9 \mathrm{~mJ} / \mathrm{m}^{2} ; \gamma^{-}(\mathrm{PP})=4.1 \mathrm{~mJ} / \mathrm{m}^{2} ; \gamma^{-}\right.$ $\left.(\mathrm{PVC})=5.3 \mathrm{~mJ} / \mathrm{m}^{2}\right)$ (Figure $2(\mathrm{c})$ ) and the valor of electron acceptor character

Table 1. Contact angle and surface energy components of the bacterium.

\begin{tabular}{ccccccccc}
\hline \multirow{2}{*}{ Surface } & \multicolumn{3}{c}{ Contact angle $\left(^{\circ}\right)$} & \multicolumn{4}{c}{ Surface energy $\left(\mathrm{mJ} / \mathrm{m}^{2}\right)$} \\
\cline { 2 - 8 } & $\theta_{d}$ & $\theta_{f}$ & $\theta_{W}$ & $\gamma^{L W}$ & $\gamma^{+}$ & $\gamma^{-}$ & $\gamma^{A B}$ & $\Delta G_{\text {iwi }}$ \\
\hline Bacterium & 43.5 & 38.6 & 33.8 & 37.5 & 0.59 & 50.62 & 10.93 & 31.1 \\
Std. dev. & 1.5 & 2 & 1.4 & 0.8 & 0.1 & 4.5 & & \\
\hline
\end{tabular}

$\mathrm{d}=$ diiodomethane, $\mathrm{f}=$ formamide and $\mathrm{w}=$ water, $\gamma^{L W}$ surface energy of Lifshitz-Van der Waals, $\gamma^{+}$electron acceptor, $\gamma$ electron donor, the $\gamma^{A B}$ Lewis acid-base surface tension and $\Delta G_{i w i}$ the free energy of interaction between two entities of that material when immersed in water. Std. dev. = Standard deviation. 


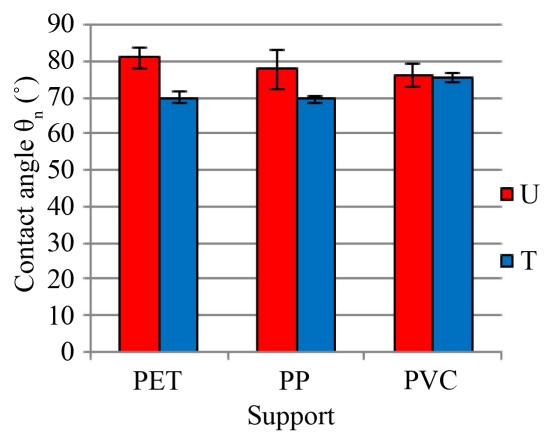

(a)

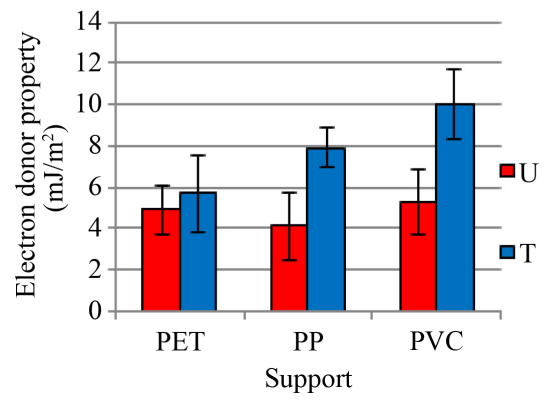

(c)

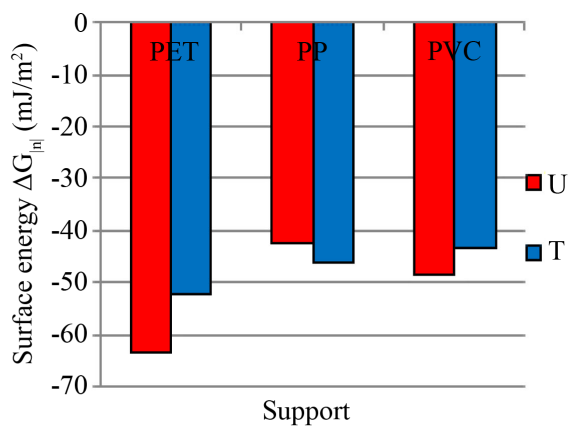

(b)

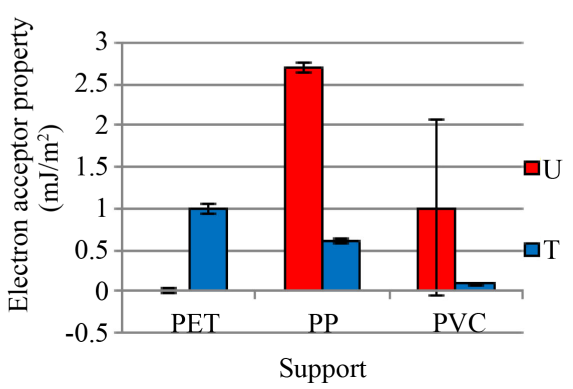

(d)

Figure 2. Physicochemical characteristics of supports (PET, PP, and PVC) untreated (U) and treated (T) with OMWW. (a) Qualitative hydrophobicity; (b) Quantitative hydrophobicity; (c) Electron donor property; (d) Electron acceptor property; U Untreated; T Treated with OMWW. The error bars represent standard deviations.

Table 2. Contact angle and surface energy of components of substrates treated and untreated with OMWW.

\begin{tabular}{ccccccccc}
\hline & \multicolumn{3}{c}{ Contact angle $\left(^{\circ}\right)$} & \multicolumn{5}{c}{ Surface energy $\left(\mathrm{mJ} / \mathrm{m}^{2}\right)$} \\
\cline { 2 - 8 } Surface & $\theta_{d}$ & $\theta_{f}$ & $\theta_{W}$ & $\gamma^{L W}$ & $\gamma^{+}$ & $\gamma$ & $\gamma^{A B}$ & $\Delta G_{\text {Iwi }}$ \\
\hline $\mathrm{PET}_{\mathrm{U}}$ & 36.8 & 57.3 & 80.9 & 41.2 & 0 & 4.9 & 0,00 & -63.2 \\
Std. dev. & 1.5 & 0.3 & 3 & 0.7 & 0 & 1.2 & & \\
$\mathrm{PET}_{\mathrm{T}}$ & 24.4 & 36.3 & 70 & 46.4 & 1 & 5.7 & 4.77 & -52.2 \\
Std. dev. & 1.6 & 1.1 & 1.4 & 0.8 & 0.1 & 1.8 & & \\
$\mathrm{PP}_{\mathrm{U}}$ & 57.6 & 50.1 & 77.8 & 30 & 2.7 & 4.1 & 6.65 & -42.3 \\
Std. dev. & 3 & 1.4 & 5.5 & 1.6 & 0.1 & 1.7 & & \\
$\mathrm{PP}_{\mathrm{T}}$ & 28.9 & 41.7 & 69.5 & 44.7 & 0.6 & 7.9 & 4.35 & -46.3 \\
Std. dev. & 1.8 & 1.7 & 0.8 & 0.8 & 0 & 1 & & \\
PVC $_{\mathrm{U}}$ & 44.5 & 49.8 & 76.3 & 37.3 & 1 & 5.3 & 4.6 & -48.5 \\
Std. dev. & 9 & 1.6 & 3.1 & 3.1 & 1.1 & 1.6 & & \\
PVC $_{\mathrm{T}}$ & 31.5 & 57.7 & 75.4 & 43.6 & 0,1 & 10 & 2,00 & -43.1 \\
Std. dev. & 0.9 & 1.3 & 1.4 & 1.4 & 0 & 1.7 & & \\
\hline
\end{tabular}

$\mathrm{U}=$ untreated supports, $\mathrm{T}=$ for support treated with OMWW and Std. dev. = Standard deviation. 
is very feeble $\left(\gamma^{+}(\mathrm{PET})=0 \mathrm{~mJ} / \mathrm{m}^{2} ; \gamma^{+}(\mathrm{PP})=2.7 \mathrm{~mJ} / \mathrm{m}^{2} ; \gamma^{+}(\mathrm{PVC})=1 \mathrm{~mJ} / \mathrm{m}^{2}\right)$ (Figure 2(d)).

After treatment, the support surfaces keep their hydrophobic characters, showing little change in their qualitative hydrophobicity $\theta_{w}\left(\theta_{w}(\mathrm{PET})=70^{\circ} ; \theta_{w}\right.$ $(\mathrm{PP})=69.5^{\circ}, \theta_{w}(\mathrm{PVC})=75.4^{\circ}$ ) (Figure $2(\mathrm{a})$ ) and quantitative hydrophobicity $\Delta G_{i w i}\left(\Delta G_{i w i}(\mathrm{PET})=-63.2 \mathrm{mj} / \mathrm{m}^{2} ; \Delta G_{i w i}(\mathrm{PP})=-42.3 \mathrm{mj} / \mathrm{m}^{2} ; \Delta G_{i w i}(\mathrm{PVC})=-48.5\right.$ $\mathrm{mj} / \mathrm{m}^{2}$ ) (Figure 2(b)). Treatment increased the valor of the electron donor $\gamma$ character $\left(\gamma^{-}(\mathrm{PET})=5.7 \mathrm{~mJ} / \mathrm{m}^{2} ; \gamma^{-}(\mathrm{PP})=7.9 \mathrm{~mJ} / \mathrm{m}^{2} ; \gamma^{-}(\mathrm{PVC})=10 \mathrm{~mJ} / \mathrm{m}^{2}\right)$ (Figure 2(c)), while the valor of electron acceptor character remained very feeble $\left(\gamma^{+}(\mathrm{PET})=1 \mathrm{~mJ} / \mathrm{m}^{2} ; \gamma^{+}(\mathrm{PP})=0.6 \mathrm{~mJ} / \mathrm{m}^{2} ; \gamma^{+}(\mathrm{PVC})=0.1 \mathrm{~mJ} / \mathrm{m}^{2}\right)($ Figure $2(d))$.

\section{Discussion}

In this study, adhesion tests of the bacterial strain were performed on polyethylene terephthalate (PET), polypropylene (PP), and polyvinyl chloride (PVC). Different results were observed between supports that were treated with OMWW and those that were untreated. In our case, the untreated supports showed a difference in bacterial adhesion (PP and PVC have twice as many adherent bacteria as PET). Which means that material nature of the support may play a role in microbial adhesion, some authors mentioned this [18] [24]. Supports treated with OMWW do not show a significant difference between them with regard to the adhesion of this bacterium. This suggests that the nature of the substrate does not affect bacterial adhesion. On the other hand, the treatment of supports with OMWW does affect the rate of bacterial adhesion (from $10^{5} \mathrm{UFC} / \mathrm{cm}^{2}$ to $10^{11} \mathrm{CFU} / \mathrm{cm}^{2}$ ). Microorganism adhesion to surfaces is, as with any inert colloidal particle, largely governed by physicochemical interactions. The sum of these interactions-including electrostatic, Lifshitz-Van der Waals, and acid-Lewis base interactions-can be attractive or repulsive. These interactions depend on the physicochemical properties of microorganisms' surface, substrate surface, and suspension medium characteristics. These physicochemical properties include hydrophobicity, electrostatic charge, and electron donor/electron acceptor character. All the factors likely to modify the physicochemical surface properties of one of the elements involved in the adhesion phenomenon can thus favor or limit microorganisms' fixation [25].

In addition, basic chemistry states that one hydrophilic entity naturally attracts another hydrophilic entity [26] and vice versa. Previous researchers [26] [27] [28] have reported that hydrophobicity cannot systematically explain the results of microbial adhesion to a support and that acid-base interactions play a very important role in the adhesion phenomenon [11] [29] [30]. According to these assertions, the adhesion of the studied bacterium on the surfaces of supports treated with OMWW may be due in part to the acid-base interactions between the strong supports' electron-donating character and the weak bacterium's electron-accepting character, which may also explain the adhesive power 
of this bacterium on treated supports with OMWW.

Hydrophobicity and electron acceptor/donor characteristics were used here to explain these results. Electrostatic forces were not taken into account because the tests were carried out in a liquid with a high ionic strength [31] [32]. It is well known that bacteria are usually charged negatively in a liquid medium [33] and OMWW has a complex constitution and contains a significant amount of minerals [34]. To avoid charge interference between the bacteria cells and the OMWW, we used high ionic strength of cell suspension.

Treatment with OMWW does alter the natural character of the three supports, with remarkable changes in the $\Delta G_{i w i}$ and $\theta_{w}$ values (Figure 2(a) and Figure 2(b)), the $\Delta G_{i w i}$ decreases slightly for the PET and PVC supports after OMWW treated and increases slightly for the PP support (Figure 2(b)). Supports hydrophobicity $\theta_{w}$ decreased after treatment with OMWW, despite the fact that OMWW contains fats. This may be due either to the fact that the hydrophilic part of the fatty acids is exposed to the outside and the hydrophobic part is adsorbed on support surface or it may be due to the cocktail effect of all the components of OMWW which contains sugars, proteins and fat that adsorb on support surface. Several authors have shown that hydrophobicity as measured by the contact angle is directly correlated with the high ratio of $\mathrm{N} / \mathrm{C}$ concentrations and inversely correlated with that of O/C concentrations [22] [35] [36] [37] [38], these results indicate that the origin of hydrophobicity measured by the contact angle is nitrogen-containing groups and the origin of hydrophilicity is oxygen-containing groups. The electron donor character value increased slightly for the PET $\left(\gamma_{U}^{-}=4.9\right.$ to $\left.\gamma_{T}^{-}=5.7\right)$ following OMWW treatment and doubled for $\operatorname{PP}\left(\gamma_{U}^{-}=4.1\right.$ to $\left.\gamma_{T}^{-}=7.9\right)$ and PVC $\left(\gamma_{U}^{-}=5.3\right.$ to $\left.\gamma_{T}^{-}=10\right)$ (Figure $\left.2(\mathrm{c})\right)$.

The contact angle method gave very detailed results in terms of hydrophobicity and electron donor/acceptor character for the three supports (PET, PP, PVC) before and after treatment with OMWW (Figure 2). From a qualitative and quantitative point of view, we found that all the untreated polymer materials have a clearly hydrophobic character. Moreover, all these materials have a low electron donor/acceptor character. Many different studies have shown the same tendency in the surface physicochemical characteristics for these untreated polymers [18] [24] [25] [39] [40] [41]. Various studies have shown that a conditioning film can be formed by several organic substances such as proteins, polysaccharides, lipids, nucleic acids, and exopolysaccharides [42] [43]. Conditioning film formation is a multi-step phenomenon; as an example, on stainless steel in a marine environment, proteins adsorb first followed by carbohydrates [44] [45] [46].

OMWW has a very complex constitution with different natures and concentrations. It contains a significant amount of carbohydrates, nitrogen compounds, fatty acids, and mineral substances and has a $\mathrm{pH}$ value between 4 and 6 [47]. As mentioned in different studies, polysaccharides can have a hydrophobic or hydrophilic character depending on the state of freedom in solution as well as their three-dimensional conformation, which can influence the physicochemical pa- 
rameters of the supports treated with OMWW [40] [48]. Hamadi et al. have shown that physicochemical parameters including hydrophobicity and electron acceptor/donor character of a stainless steel surface can be modified by fatty acid and proteins after conditioning by milk [19].

In our case, the modification of the three supports' physicochemical characteristics (hydrophobicity and electron donor/acceptor character) is due to OMWW properties (carbohydrate, protein and fat content). The concentration and type of molecules adsorbed on the surface of a material are conditioned by the nature of this material $\left(\Delta G_{i w>}\right.$ hydrophobicity, electron donor/acceptor character, electrostatic charges, etc.) [49] [50]. This may explain the differences we found concerning hydrophobicity and electron donor/acceptor character between the untreated and treated supports.

The more the hydrophobicity decreases, the more the bacterial adhesion increases for untreated supports. Our results align with the work of Pringle and Fletcher [51] who found a relationship between the contact angle to water (varies from $0^{\circ}$ to $110^{\circ}$ ) and the adhesion of different bacteria on four different surfaces. Also, Absolom et al. [52] showed a linear relationship between the contact angle to water of different varieties of polymers (ranging from $58^{\circ}$ to $110^{\circ}$ ) and bacterial adhesion. The adhesion of bacteria on surfaces of untreated substrates is not correlated with the electron donor character $\left(R^{2}=0.007\right)$. Inversely, the experimental adhesion on treated surfaces correlates well with the electron donor character $\left(R^{2}=0.93\right)$. The greater the electron donor character of the support, the more the bacterial adhesion decreases.

\section{Conclusions}

The bacterium has a very pronounced hydrophilic character both qualitatively and quantitatively and a strong donor electron character.

Untreated supports with OMWW have a hydrophobic character and a very weak electron acceptor/donor character.

After treatment, the supports retained their hydrophobic character with little change compared to untreated supports. The electron donor character of treated substrates doubled for PP and PVC.

Bacterial adhesion to untreated supports is affected by hydrophobicity. In fact, the more the hydrophobicity decreases, the more the bacterial adhesion increases, and the amount of cell adherence is double for PVC and PP compared to PET for untreated supports. After treatment with OMWW, the greater the electron donor character of the support, the more the bacterial adhesion decreases; for treated supports, the amount of cell adherence for PET is double than that of PVS and PP 1.7 times than that of PVC. The conditioning film of OMWW significantly enhanced the bacterial adhesion for all three supports (from $10^{5}$ $\mathrm{UFC} / \mathrm{cm}^{2}$ to $10^{11} \mathrm{CFU} / \mathrm{cm}^{2}$ ).

In conclusion, the choice of support material impacts bacterial adhesion, especially after taking into account the OMWW conditioning film, which promotes a high level of bacterial adhesion. 


\section{Conflicts of Interest}

The authors declare no conflict of interest.

\section{References}

[1] Zagklis, D.P., Vavouraki, A.I., Kornaros, M.E. and Paraskeva, C.A. (2015) Purification of Olive Mill Wastewater Phenols through Membrane Filtration and Resin Adsorption/Desorption. Journal of Hazardous Materials, 285, 69-76. https://doi.org/10.1016/j.jhazmat.2014.11.038

[2] Ochando-Pulido, J.M., Rodriguez-Vives, S., Hodaifa, G. and Martinez-Ferez, A. (2012) Impacts of Operating Conditions on Reverse Osmosis Performance of Pretreated Olive Mill Wastewater. Water Research, 46, 4621-4632. https://doi.org/10.1016/j.watres.2012.06.026

[3] Gotsi, M., Kalogerakis, N., Psillakis, E., Samaras, P. and Mantzavinos, D. (2005) Electrochemical Oxidation of Olive Oil Mill Wastewaters. Water Research, 39, 4177-4187. https://doi.org/10.1016/j.watres.2005.07.037

[4] Cabrera, F., López, R., Martinez-Bordiú, A., De Dupuy Lome, E. and Murillo, J.M. (1996) Land Treatment of Olive Oil Mill Wastewater. International Biodeterioration and Biodegradation, 38, 215-225. https://doi.org/10.1016/S0964-8305(96)00054-6

[5] Rincón, B., Borja, R., Martín, M.A. and Martín, A. (2009) Evaluation of the Methanogenic Step of a Two-Stage Anaerobic Digestion Process of Acidified Olive Mill Solid Residue from a Previous Hydrolytic-Acidogenic Step. Waste Management, 29, 2566-2573. https://doi.org/10.1016/j.wasman.2009.04.009

[6] Olivieri, G., Marzocchella, A., Salatino, P., Giardina, P., Cennamo, G. and Sannia, G. (2006) Olive Mill Wastewater Remediation by Means of Pleurotus ostreatus. Biochemical Engineering Journal, 31, 180-187. https://doi.org/10.1016/j.bej.2006.07.005

[7] Weiland, P. (2010) Biogas Production: Current State and Perspectives. Applied Microbiology and Biotechnology, 85, 849-860. https://doi.org/10.1007/s00253-009-2246-7

[8] Muñoz Sierra, J.D., Oosterkamp, M.J., Wang, W., Spanjers, H. and van Lier, J.B. (2019) Comparative Performance of Upflow Anaerobic Sludge Blanket Reactor and Anaerobic Membrane Bioreactor Treating Phenolic Wastewater: Overcoming High Salinity. Chemical Engineering Journal, 366, 480-490.

https://doi.org/10.1016/j.cej.2019.02.097

[9] Mao, Y., Quan, X., Zhao, H., Zhang, Y., Chen, S., Liu, T. and Quan, W. (2017) Accelerated Startup of Moving Bed Biofilm Process with Novel Electrophilic Suspended Biofilm Carriers. Chemical Engineering Journal, 315, 364-372. https://doi.org/10.1016/j.cej.2017.01.041

[10] da Silva, A.N., Macêdo, W.V., Sakamoto, I.K., Pereyra, D. de L.A.D., Mendes, C.O., Maintinguer, S.I., Caffaro Filho, R.A., Damianovic, M.H.Z., Varesche, M.B.A. and de Amorim, E.L.C. (2019) Biohydrogen Production from Dairy Industry Wastewater in an Anaerobic Fluidized-Bed Reactor. Biomass and Bioenergy, 120, 257-264. https://doi.org/10.1016/j.biombioe.2018.11.025

[11] Hamadi, F., Latrache, H., Mabrrouki, M., Elghmari, A., Outzourhit, A., Ellouali, M. and Chtaini, A. (2005) Effect of $\mathrm{pH}$ on Distribution and Adhesion of Staphylococcus aureus to Glass. Journal of Adhesion Science and Technology, 19, 73-85. https://doi.org/10.1163/1568561053066891

[12] Tang, B., Yu, C., Bin, L., Zhao, Y., Feng, X., Huang, S., Fu, F., Ding, J., Chen, C., Li, 
P. and Chen, Q. (2016) Essential Factors of an Integrated Moving Bed Biofilm Reactor-Membrane Bioreactor: Adhesion Characteristics and Microbial Community of the Biofilm. Bioresource Technology, 211, 574-583. https://doi.org/10.1016/j.biortech.2016.03.136

[13] Liu, Y., Yang, S.F., Tay, J.H., Liu, Q.S., Qin, L. and Li, Y. (2004) Cell Hydrophobicity Is a Triggering Force of Biogranulation. Enzyme and Microbial Technology, 34, 371-379. https://doi.org/10.1016/j.enzmictec.2003.12.009

[14] Oh, Y.J., Lee, N.R., Jo, W., Jung, W.K. and Lim, J.S. (2009) Effects of Substrates on Biofilm Formation Observed by Atomic Force Microscopy. Ultramicroscopy, 109, 874-880. https://doi.org/10.1016/j.ultramic.2009.03.042

[15] Kanematsu, H. and Barry, D.M. (2015) Biofilm and Materials Science. Springer, Berlin. https://doi.org/10.1007/978-3-319-14565-5

[16] Afilal, M.E., Belkhadi, H., Daoudi, N. and Elasri, O. (2013) Methanic Fermentation of Different Organic Substrates. Journal of Materials and Environmental Science, 4, 11-16.

[17] Buldini, P.L., Mevoli, A. and Quirini, A. (2000) On-Line Microdialysis-Ion Chromatographic Determination of Inorganic Anions in Olive-Oil Mill Wastewater. Journal of Chromatography $A, \mathbf{8 8 2}, 321-328$. https://doi.org/10.1016/S0021-9673(00)00434-9

[18] Nguyen, V., Karunakaran, E., Collins, G. and Biggs, C.A. (2016) Physicochemical Analysis of Initial Adhesion and Biofilm Formation of Methanosarcina barkeri on Polymer Support Material. Colloids and Surfaces B: Biointerfaces, 143, 518-525. https://doi.org/10.1016/j.colsurfb.2016.03.042

[19] Hamadi, F., Latrache, H., Asserne, F., Elabed, S., Zahir, H., Saad, I.K., Hanine, H. and Bengourram, J. (2013) Quantitative Adhesion of Staphylococcus aureus on Stainless Steel Coated with Milk. Food and Nutrition Sciences, 4, 299-304. https://doi.org/10.4236/fns.2013.43040

[20] Busscher, H.J., Weerkamp, A.H., van Der Mei, H.C., van Pelt, A.W., de Jong, H.P. and Arends, J. (1984) Measurement of the Surface Free Energy of Bacterial Cell Surfaces and Its Relevance for Adhesion. Applied and Environmental Microbiology, 48, 980-983. https://doi.org/10.1128/AEM.48.5.980-983.1984

[21] Van Oss, C.J., Chaudhury, M.K. and Good, R.J. (1988) Interfacial Lifshitz-van der Waals and Polar Interactions in Macroscopic Systems. Chemical Reviews, 88, 927-941. https://doi.org/10.1021/cr00088a006

[22] Latrache, H., El Ghmari, A., Karroua, M., Hakkou, A., Ait Mousse, H., El Bouadili, A. and Bourlioux, P. (2002) Relations between Hydrophobicity Tested by Three Methods and Surface Chemical Composition of Escherichia coli. New Microbiologica, 25, 75-82.

[23] Van Oss, C.J. (1995) Hydrophobicity of Biosurfaces-Origin, Quantitative Determination and Interaction Energies. Colloids and Surfaces B: Biointerfaces, 5, 91-110. https://doi.org/10.1016/0927-7765(95)01217-7

[24] Habouzit, F., Gévaudan, G., Hamelin, J., Steyer, J.P. and Bernet, N. (2011) Influence of Support Material Properties on the Potential Selection of Archaea during Initial Adhesion of a Methanogenic Consortium. Bioresource Technology, 102, 4054-4060. https://doi.org/10.1016/j.biortech.2010.12.023

[25] van Oss, C.J. (2006) Interfacial Forces in Aqueous Media. Second Edition, CRC Press, Boca Raton. https://doi.org/10.1201/9781420015768

[26] McEldowney, S. and Fletcher, M. (1986) Variability of the Influence of Physicochemical Factors Affecting Bacterial Adhesion to Polystyrene Substrata. Applied 
and Environmental Microbiology, 52, 460-465.

https://doi.org/10.1128/AEM.52.3.460-465.1986

[27] Pratt-Terpstra, I.H., Weerkamp, A.H. and Busscher, H.J. (1988) On a Relation between Interfacial Free Energy-Dependent and Noninterfacial Free Energy-Dependent Adherence of Oral Streptococci to Solid Substrata. Current Microbiology, 16, 311-313. https://doi.org/10.1007/BF01568537

[28] Sjollema, J., Van der Mei, H.C., Uyen, H.M.W. and Busscher, H.J. (1990) The Influence of Collector and Bacterial Cell Surface Properties on the Deposition of Oral Streptococci in a Parallel Plate Flow Cell. Journal of Adhesion Science and Technology, 4, 765-777. https://doi.org/10.1163/156856190X00658

[29] Hamadi, F., Latrache, H., Mallouki, B., Mliji, E., El Ghmari, A., Mabrouki, M., Bengourram, J. and Ellouali, M. (2008) Adhesion of Escherichia coli to Glass under Different pH. Journal of Pure and Applied Microbiology, 2, 295-302.

[30] Henriques, M., Azeredo, J. and Oliveira, R. (2004) Adhesion of Candida albicans and Candida dubliniensis to Acrylic and Hydroxyapatite. Colloids and Surfaces B: Biointerfaces, 33, 235-241. https://doi.org/10.1016/j.colsurfb.2003.10.012

[31] Bellon-Fontaine, M.N., Rault, J. and Van Oss, C.J. (1996) Microbial Adhesion to Solvents: A Novel Method to Determine the Electron-Donor/Electron-Acceptor or Lewis Acid-Base Properties of Microbial Cells. Colloids and Surfaces B: Biointerfaces, 7, 47-53. https://doi.org/10.1016/0927-7765(96)01272-6

[32] Gallardo-Moreno, A.M., González-Martín, M.L., Pérez-Giraldo, C., Bruque, J.M. and Gómez-García, A.C. (2004) The Measurement Temperature: An Important Factor Relating Physicochemical and Adhesive Properties of Yeast Cells to Biomaterials. Journal of Colloid and Interface Science, 271, 351-358. https://doi.org/10.1016/j.jcis.2003.12.008

[33] van Loosdrecht, M.C.M., Lyklema, J., Norde, W. and Zehnder, A.J.B. (1989) Bacterial Adhesion: A Physicochemical Approach. Microbial Ecology, 17, 1-15. https://doi.org/10.1007/BF02025589

[34] Dermeche, S., Nadour, M., Larroche, C., Moulti-Mati, F. and Michaud, P. (2013) Olive Mill Wastes: Biochemical Characterizations and Valorization Strategies. Process Biochemistry, 48, 1532-1552. https://doi.org/10.1016/j.procbio.2013.07.010

[35] Mozes, N., Léonard, A. and Rouxhet, P.G. (1988) On the Relations between the Elemental Surface Composition of Yeasts and Bacteria and Their Charge and Hydrophobicity, Biochimica et Biophysica Acta (BBA)-Biomembranes, 945, 324-334.

[36] Cowan, M.M., Van der Mei, H.C., Rouxhet, P.G. and Busscher, H.J. (1992) Physico-Chemical and Structural Properties of the Surfaces of Peptostreptococcus micros and Streptococcus mitis as Compared to Those of Streptococcus mutans, Streptococcus sanguis and Streptococcus salivarius. Microbiology, 138, 2707-2714. https://doi.org/10.1099/00221287-138-12-2707

[37] van der Mei, H.C. and Busscher, H.J. (1997) The Use of X-Ray Photoelectron Spectroscopy for the Study of Oral Streptococcal Cell Surfaces. Advances in Dental Research, 11, 388-394. https://doi.org/10.1177/08959374970110040301

[38] Latrache, H., Mozes, N., Pelletier, C. and Bourlioux, P. (1994) Chemical and Physicochemical Properties of Escherichia coli: Variations among Three Strains and Influence of Culture Conditions. Colloids and Surfaces B: Biointerfaces, 2, 47-56. https://doi.org/10.1016/0927-7765(94)80017-0

[39] Assaidi, A., Ellouali, M., Latrache, H., Mabrouki, M., Timinouni, M., Zahir, H., Tankiouine, S., Barguigua, A. and Mliji, E.M. (2018) Adhesion of Legionella pneumophila on Glass and Plumbing Materials Commonly Used in Domestic Water 
Systems. International Journal of Environmental Health Research, 28, 125-133. https://doi.org/10.1080/09603123.2018.1429580

[40] Van Oss, C.J., Chaudhury, M.K. and Good, R.J. (1989) The Mechanism of Phase Separation of Polymers in Organic Media-A Polar and Polar Systems. Separation Science and Technology, 24, 15-30. https://doi.org/10.1080/01496398908049748

[41] Oss, C.J.V., Good, R.J. and Busscher, H.J. (1990) Estimation of the Polar Surface Tension Parameters of Glycerol and Formamide, for Use in Contact Angle Measurements on Polar Solids. Journal of Dispersion Science and Technology, 11, 75-81.

[42] Taylor, G.T., Zheng, D., Lee, M., Troy, P.J., Gyananath, G. and Sharma, S.K. (1997) Influence of Surface Properties on Accumulation of Conditioning Films and Marine Bacteria on Substrata Exposed to Oligotrophic Waters. Biofouling, 11, 31-57. https://doi.org/10.1080/08927019709378319

[43] Zaidi, B.R., Bard, R.F. and Tosteson, T.R. (1984) Microbial Specificity of Metallic Surfaces Exposed to Ambient Seawater. Applied and Environmental Microbiology, 48, 519-524. https://doi.org/10.1128/AEM.48.3.519-524.1984

[44] Compère, C., Bellon-Fontaine, M.N., Bertrand, P., Costa, D., Marcus, P., Poleunis, C., Pradier, C.M., Rondot, B. and Walls, M.G. (2001) Kinetics of Conditioning Layer Formation on Stainless Steel Immersed in Seawater. Biofouling, 17, 129-145. https://doi.org/10.1080/08927010109378472

[45] Poleunis, C., Compère, C. and Bertrand, P. (2002) Time-of-Flight Secondary Ion Mass Spectrometry: Characterisation of Stainless Steel Surfaces Immersed in Natural Seawater. Journal of Microbiological Methods, 48, 195-205. https://doi.org/10.1016/S0167-7012(01)00323-2

[46] Poleunis, C., Rubio, C., Compere, C. and Bertrand, P. (2003) ToF-SIMS Chemical Mapping Study of Protein Adsorption onto Stainless Steel Surfaces Immersed in Saline Aqueous Solutions. Applied Surface Science, 203, 693-697.

[47] Paraskeva, C.A., Papadakis, V.G., Tsarouchi, E., Kanellopoulou, D.G. and Koutsoukos, P.G. (2007) Membrane Processing for Olive Mill Wastewater Fractionation. Desalination, 213, 218-229. https://doi.org/10.1016/j.desal.2006.04.087

[48] Van Oss, C.J. (2006) Interfacial Forces in Aqueous Media. 2nd Edition, Vol. 36, Taylor and Francis Group, Abingdon-on-Thames. https://doi.org/10.1201/9781420015768

[49] Rosmaninho, R., Santos, O., Nylander, T., Paulsson, M., Beuf, M., Benezech, T., Yiantsios, S., Andritsos, N., Karabelas, A., Rizzo, G., Müller-Steinhagen, H. and Melo, L.F. (2007) Modified Stainless Steel Surfaces Targeted to Reduce Fouling-Evaluation of Fouling by Milk Components. Journal of Food Engineering, 80, 1176-1187. https://doi.org/10.1016/j.jfoodeng.2006.09.008

[50] Rubio, C., Costa, D., Bellon-Fontaine, M.N., Relkin, P., Pradier, C.M. and Marcus, P. (2002) Characterization of Bovine Serum Albumin Adsorption on Chromium and AISI 304 Stainless Steel, Consequences for the Pseudomonas fragi K1 Adhesion. Colloids and Surfaces B: Biointerfaces, 24, 193-205. https://doi.org/10.1016/S0927-7765(01)00242-9

[51] Pringle, J.H. and Fletcher, M. (1983) Influence of Substratum Wettability on Attachment of Freshwater Bacteria to Solid Surfaces. Applied and Environmental Microbiology, 45, 811-817. https://doi.org/10.1128/AEM.45.3.811-817.1983

[52] Absolom, D.R., Lamberti, F.V., Policova, Z., Zingg, W., van Oss, C.J. and Neumann, A.W. (1983) Surface Thermodynamics of Bacterial Adhesion. Applied and Environmental Microbiology, 46, 90-97. https://doi.org/10.1128/AEM.46.1.90-97.1983 